\title{
Stosunek administracyjnoprawny w niemieckiej doktrynie prawa publicznego*
}

\section{Wprowadzenie}

Pojęcie stosunku administracyjnoprawnego jest jądrem dogmatyki polskiego prawa administracyjnego - dla nauki prawa i postępowania administracyjnego ma znaczenie centralne, ponadczasowe. Na przestrzeni lat zostały ustalone przez doktrynę prawa publicznego jego ramy doktrynalne. Równocześnie niezwykle owocna dyskusja dogmatyczna na temat tego pojęcia miała miejsce na gruncie prawa i praktyki niemieckiej. Dlatego też zasadna wydaje się próba przedstawienia odkryć niemieckiej doktryny prawa publicznego w tym zakresie. Tym samym może się wydawać, że artykuł ma charakter wyłącznie deskryptywny. Jednakże, oprócz przedstawienia najważniejszych poglądów na ten temat, zadane jest udzielenie odpowiedzi, lub przynajmniej zapoczątkowanie dyskusji, na kilka ważnych dla dogmatyki polskiego prawa administracyjnego pytań - o czym szerzej w dalszej części wprowadzenia.

Szczególnie, w obliczu pogłębionych rozważań w prawie i praktyce polskiej na tle umowy administracyjnej w systemie prawnych form działania administracji, istotnego znaczenia nabiera klaryfikacja podstawowych pojęć $\mathrm{z}$ zakresu prawa administracyjnego. Tym samym warto sięgnąć do zagadnienia stosunku administracyjnoprawnego. Nie można również przeoczyć faktu, że pojęcie stosunku administracyjnoprawnego (względnie prywatnoprawnego) jest w dogmatyce prawa podstawą kluczowego podziału na prawo publiczne oraz prywatne. Tym bardziej

* Paweł Sancewicz, dr, Universität Potsdam, e-mail: psancewicz@uni-potsdam.de, https://orcid.org/0000-0001-5475-0956. Artykuł powstał w ramach stypendium przyznanego przez fundację Fritz Thyssen Stiftung, w ramach postępowania o sygn. 40.18.0.011RE na pobyt badawczy w Kommunalwissenschaftliches Institut (KWI) der Universität Potsdam. 
dalsze prace nad stosunkiem administracyjnoprawnym nie będą narażone na zarzut braku aktualności, lecz powinny wnieść istotny wkład w badania zmierzające do wprowadzenia umowy administracyjnej do polskiego systemu prawnego. Funkcjonowanie umowy administracyjnej w polskim porządku prawnym będzie wymagało zrewidowania pojęcia stosunku administracyjnoprawnego. Pojęcie to jest bowiem dostosowane do władczej i jednostronnej czynności, jaką jest indywidualny akt administracyjny, nie zaś do wielostronnej, konsensualnej i kooperacyjnej prawnej formy działania administracji, jaką jest umowa administracyjna.

Pojęcie stosunku administracyjnoprawnego występuje w nauce prawa publicznego licznych krajów, nie tylko Niemiec, lecz przykładowo także w nauce francuskiej, austriackiej lub rosyjskiej. Jednakże to nauka niemiecka wielokrotnie była inspiracją do formułowania poglądów na temat stosunku administracyjnoprawnego. Oprócz ograniczeń objętościowych jest to kolejny powód, dla którego doktryna niemiecka $\mathrm{w}$ omawianym zakresie stała się przedmiotem artykułu.

Celem podjętych badań jest ukazanie, czy doktryna niemieckiego prawa publicznego rozumie pojęcie stosunku administracyjnoprawnego w podobny sposób co doktryna polska, czy też widzi to pojęcie inaczej. Udzielenie odpowiedzi na powyższe pytanie wydaje się szczególnie interesujące, zważywszy na fakt, że w Niemczech obowiązuje inny system prawnych form działania administracji publicznej, którego częścią składową jest umowa administracyjna. Ponadto analiza pojęcia stosunku administracyjnoprawnego jest aktualna zarówno w Polsce, jak i w Niemczech, gdzie w obliczu postępujących procesów modernizacyjnych występuje powszechne dążenie $\mathrm{w}$ kierunku administracji bardziej kooperacyjnej, nastawionej na współpracę z podmiotami administrowanymi. Wreszcie należy się zastanowić, czy wprowadzaniu umowy administracyjnej do prawa niemieckiego towarzyszyła zmiana postrzegania pojęcia stosunku administracyjnoprawnego i czy ten sam proces będzie miał miejsce w polskiej doktrynie prawa publicznego.

\section{Użyteczność pojęcia stosunku administracyjnoprawnego dla dogmatyki prawniczej}

Tak jak wspomniano powyżej, pojęcie stosunku administracyjnoprawnego nie jest przebrzmiałe. Powyższe stwierdzenie dotyczy zarówno prawa polskiego, jak i niemieckiego. Duża przydatność teoretyczna 
tego pojęcia jest potwierdzona w licznych podręcznikach do prawa administracyjnego ${ }^{1}$. Również niemiecka doktryna prawa publicznego w artykułach naukowych i opracowaniach o charakterze monograficznym toczyła spory na temat użyteczności poznawczej analizowanego pojęcia ${ }^{2}$. Stosunek administracyjnoprawny jest widziany przez niektórych badaczy jako podstawowe pojęcie, prawnicza świętość albo jako punkt archimedejski ${ }^{3}$. Reprezentujący przeciwny nurt przedstawiciele doktryny wskazują, że stosunek administracyjnoprawny jest pozbawiony konturów bądź treści ${ }^{4}$. Niektórzy podkreślają nawet, że pojęcie to nie ma większej wartości poznawczej ${ }^{5}$. W niemieckim prawie

${ }^{1}$ Por. R. Hauser, Pojeccie i znaczenie stosunku administracyjnoprawnego, w: System prawa administracyjnego, t. 1, Instytucje prawa administracyjnego, pod red. R. Hausera, Z. Niewiadomskiego, A. Wróbla, Warszawa 2015, s. 200. W polskim prawie administracyjnym np.: J. Boć, Pojęcie stosunku administracyjnoprawnego, w: idem, Prawo administracyjne, Wrocław 2010, s. 365 i n.; Z. Leoński, Stosunek administracyjnoprawny, w: idem, Zarys prawa administracyjnego, Warszawa 2006, s. 32 i n.; E. Ochendowski, Prawo administracyjne. Czesść ogólna, Toruń 2009, s. 45 i n.; Z. Cieślak, Stosunek administracyjnoprawny, w: Prawo administracyjne, pod red. Z. Niewiadomskiego, Warszawa 2007, s. 90 i n.; Z. Duniewska, Stosunek administracyjnoprawny. Sytuacja administracyjnoprawna, w: Z. Duniewska, B. Jaworska-Dębska, M. Kasiński, E. Olejniczak-Szałowska, M. Stahl, Prawo administracyjne. Pojęcia, instytucje, zasady w teorii i orzecznictwie, pod red. M. Stahl, Warszawa 2013, s. 77 i n.; J. Zimmermann, Prawo administracyjne, Warszawa 2018, s. 72 i n.; Prawo administracyjne, pod red. M. Wierzbowskiego, Warszawa 2013, s. 26. W niemieckim prawie administracyjnym np. H. Maurer, Ogólne prawo administracyjne (Allgemeines Verwaltungsrecht), tłum. i red. K. Nowacki, Wrocław 2003, s. 110 i n.; E. Schmidt-Aßmann, Ogólne prawo administracyjne jako idea porzadku. Założenia i zadania tworzenia systemu prawnoadministracyjnego, tłum. i red. A. Wasilewski, Warszawa 2011, s. 16 i n., 383 i n.; S. Detterbeck, Allgemeines Verwaltungsrecht mit Verwaltungsprozessrecht, München 2016, s. 126 i n.; R. Stober, Verwaltungsrecht I. Ein Studienbuch, München 2017, Nb. 35 i n. Z żalem należy stwierdzić, że obecnie pojęcie stosunku administracyjnoprawnego rzadziej stanowi przedmiot zainteresowania niemieckiej doktryny prawa publicznego. Z najnowszych prac zob. J. Buchheim, Das Vorrecht des Ersten Zugriffs auf das Verwaltungsrechtsverhältnis. Das französische "privilège du préalable" als leistungsfähiger Begriff deutscher Verwaltungsrechtsdogmatik?, „Die Verwaltung” 2016, z. 1, s. 55-79; J. Ipsen, Neue Entwicklungen im Allgemeinen Verwaltungsrecht - Rechtsverhältnislehre versus Steuerungswissenschaft?, „AD LEGENDUM” 2011, z. 2, s. 100-104; W. Kahl, W.L. Ohlendorf, Das subjektive öffentliche Recht - Grundlagen und aktuelle Entwicklungen im nationalen Recht, "Juristische Arbeitsblätter" 2010, z. 12, s. 872-879; H. Schmitz, $\S 9$ Begriff des Verwaltungsverfahrens, w: Verwaltungsverfahrensgesetz. Kommentar, Hrsg. von P. Stelkens, H.J. Bonk, M. Sachs, München 2018, Nb. 16-24.

${ }^{2}$ Por. obszerny przegląd literatury dokonany przez H. Bauera - H. Bauer, Verwaltungsrechtslehre im Umbruch? Rechtsformen und Rechtsverhältnisse als Elemente einer zeitgemäßen Verwaltungsrechtsdogmatik, "Die Verwaltung” 1992, z. 1-4, s. 307 i n.

${ }^{3}$ Ibidem, s. 307-308 i n.

${ }^{4}$ Ibidem.

${ }^{5}$ Ibidem. 
administracyjnym stosunek administracyjnoprawny zdobył wszakże uznanie - pomógł ustrukturyzować miliony stosunków prawnych między administracją a obywatelem ${ }^{6}$. Klasyk niemieckiego prawa administracyjnego E. Schmidt-Aßmann wskazywał na generalnie pozytywną funkcję pojęcia stosunku administracyjnoprawnego, który skłania do całościowego ujmowania stosunków społeczno-gospodarczych (również w obszarze publicznego prawa gospodarczego $)^{7}$. Stosunek administracyjnoprawny pozwala się skupić na wzajemnych prawach i obowiązkach, na wymiarze czasowym prawa administracyjnego, a także na szczególnych cechach danego stanu faktycznego i prawnego ${ }^{8}$. R. Gröschner stoi na stanowisku, że stosunek administracyjnoprawny jest użytecznym pojęciem zarówno z punktu widzenia dogmatycznego i teoretycznego, jak i praktyki stosowania prawa9 ${ }^{9}$. W Niemczech powszechne wydaje się dążenie do nowego uporządkowania dogmatyki prawa administracyjnego właśnie za pomocą pojęcia stosunku administracyjnoprawnego ${ }^{10}$. Sceptycznie do nauki o stosunku administracyjnoprawnym podchodzi S. Detterbeck - autor wskazuje, że jakkolwiek pozwala ona uporządkować złożone i wielostronne stosunki z zakresu prawa administracyjnego, to nie przyczynia się do rozwiązywania konkretnych problemów prawnych $^{11}$.

Zdaniem E. Schmidta-Aßmanna nie jest jednak możliwe budowanie systematyki całego prawa administracyjnego na podstawie samych tylko stosunków administracyjnoprawnych ${ }^{12}$. Stosunek administracyjnoprawny może jedynie pewne problemy uwidaczniać, nie jest natomiast przeznaczony do ich rozwiązywania ${ }^{13}$. Nie może przy tym zastąpić

${ }^{6}$ F. Hase, Das Verwaltungsrechtsverhältnis. Überlegungen zu einem Grundbegriff des Öffentlichen Rechts, "Die Verwaltung” 2005, z. 1-4, s. 456 i n.

${ }^{7}$ E. Schmidt-Aßmann, Die Lehre von den Rechtsformen des Verwaltungshandelns. Ihre Bedeutung im System des Verwaltungsrechts und für das verwaltungsrechtliche Denken der Gegenwart, "Deutsches Verwaltungsblatt” 1989, s. 533, 539 i n., podaję za: J. Pietzcker, Das Verwaltungsrechtsverhältnis - archimedischer Punkt oder Münchhausens Zopf?, „Die Verwaltung" 1997, z. 1-4, s. 292.

${ }^{8}$ E. Schmidt-Aßmann, Die Lehre von den Rechtsformen..., s. 533, 539 i n.

${ }_{9}^{9}$ R. Gröschner, Vom Nutzen des Verwaltungsrechtsverhältnis, "Die Verwaltung" 1997, z. 1-4, s. 301 i n.

${ }^{10}$ S. Detterbeck, op. cit., s. 127, Nb. 415.

${ }^{11}$ Ibidem.

${ }^{12}$ E. Schmidt-Aßmann, Das allgemeine Verwaltungsrecht als Ordnungsidee und System: insbesondere zur Bedeutung von Rechtsform und Verfahren im Verwaltungsrecht, Heidelberg 1982, s. 26 i n., podaję za: R. Stober, op. cit., Nb. 38a.

${ }^{13}$ Ibidem. 
takich dogmatycznie utrwalonych kategorii, jak prawne formy działania administracji czy publiczne prawa podmiotowe (subjektive öffentliche Rechte $)^{14}$. Użyteczność tego pojęcia znajduje zaś egzemplifikację w toku analizy kooperacyjnych stosunków administracyjnoprawnych ${ }^{15}$.

Niezależnie od powyższego myślenie w kategoriach stosunku administracyjnoprawnego prowadzi do rozwoju nowych poglądów, a także do przezwyciężenia strukturalnych słabości prawa administracyjnego ${ }^{16}$. Powyższe pozwala w szczególności na uwzględnienie w analizie dogmatycznoprawnej praw i obowiązków o charakterze akcesoryjnym ${ }^{17}$.

Wydaje się przy tym, że przedstawiciele niemieckiej doktryny prawa publicznego są do analizowanego pojęcia, w kontekście stosowania go do wyjaśnienia bardziej złożonych konstrukcji prawnych niż indywidualny akt administracyjny, bardziej pozytywnie nastawieni niż badacze polscy. Nie budzi wątpliwości w niemieckiej nauce, że stosunek administracyjnoprawny występuje również w przypadku umowy administracyjnej. Ponadto, tak jak prawne formy działania stanowią "ujęcia momentalne" (Momentaufnahmen), tak stosunek administracyjnoprawny nadaje się do opisywania kompleksu czynności podejmowanych przez administrację, a także zespołu praw i obowiązków przysługujących obywatelom. Nie można jednak przeoczyć faktu, że w doktrynie niemieckiej miała miejsce ożywiona dyskusja, w ramach której w ogóle wyraźnie kwestionowano potrzebę stosowania pojęcia stosunku administracyjnoprawnego.

W polskiej doktrynie natomiast stosunek administracyjnoprawny per se nie jest kwestionowany, zwłaszcza powszechnie wykorzystuje się to pojęcie przy analizie indywidualnego aktu administracyjnego. W tym kontekście stosunek administracyjnoprawny znajduje wśród

${ }^{14}$ Ibidem.

${ }^{15}$ Ibidem. W doktrynie niemieckiej H. Bauer wskazuje na trend "państwa kooperującego": „Der Staat steigt vom hoheitlich-hoheitsvollen Podest des einseitig Anweisenden herab, er Tritt auf die Ebene des Austausches von Informationen und Leistungen und der Verbindung zu abgestimmten Handeln" (H. Bauer, Entwicklungslinien der Vertragsrechtslehre, w: Grundlagen des Verwaltungsrecht, Bd. 2: Informationsordnung, Verwaltungsverfahren, Handlungsformen, Hrsg. von W. Hoffmann-Riem, E. Schmidt-Assmann, A. Voßkuhle, München 2012, s. 1266 i n.; por. idem, Zur notwendigen Entwicklung eines Verwaltungskooperationsrechts - Statement, w: Jenseits von Privatisierung und "schlankem" Staat: Verantwortungsteilung als Schlüsselbegriff eines sich verändernden Verhältnisses von öffentlichem und privatem Sektor, Hrsg. von G.F. Schuppert, Baden-Baden 1999, s. 251 i n., podaję za: R. Stober, op. cit., Nb. 38a).

${ }^{16}$ R. Stober, op. cit., Nb. 39.

17 A. Peters, Nebenpflichten im Verwaltungsrechtsverhältnis?, „Die Verwaltung” 2002, s. 177-221, podaję za: R. Stober, op. cit., Nb. 39. 
przedstawicieli polskiej nauki powszechną akceptację. Podjęto jednak dyskusję na temat równoległego czy zastępczego stosowania innych pojęć, które lepiej ujmowałyby kompleksowe problemy prawne ${ }^{18}$. W polskiej doktrynie niekiedy postuluje się zastąpienie pojęcia stosunku administracyjnoprawnego ${ }^{19}$ pojęciem sytuacji administracyjnoprawnej ${ }^{20}$ lub statusu administracyjnoprawnego ${ }^{21}$. Należy jednak podkreślić, że większość autorów nie przedstawia tutaj skrajnego stanowiska - autorzy wskazują tylko na możliwość dodatkowego stosowania innych pojęć, zwłaszcza w sytuacji administracyjnoprawnej22. Należy przy tym podkreślić, że sytuacja administracyjnoprawna wyraźnie odróżniana jest w nauce prawa administracyjnego od pojęcia stosunku administracyjnoprawnego ${ }^{23}$.

${ }^{18}$ R. Hauser, op. cit., s. 200 i n. "Jeśli sytuacja społeczna regulowana jest przez przepisy prawa administracyjnego, to będziemy mieli do czynienia z sytuacją administracyjnoprawną. Pojęcie sytuacji administracyjnoprawnej ma, zdaniem jej zwolenników, pozwolić na szersze spojrzenie na prawa i obowiązki podmiotów prawnych określane prawem administracyjnym" (R. Hauser, op. cit., s. 215); F. Geburczyk, Zjawisko proceduralizacji w prawie administracyjnym a kierunki ewolucji procedury administracyjnej, Warszawa 2019, s. 87 i n. „[...] rozwiązania ustawowe wpisujące się w proces proceduralizacji prawa administracyjnego wywierają presję strukturalną na pojęcie stosunku administracyjnoprawnego, nie zmieniając jego zasadniczej treści w całości, ale z pewnością ją modyfikując" (F. Geburczyk, op. cit., s. 104).

${ }^{19}$ W. Dawidowicz, Polskie prawo administracyjne, Warszawa 1978, s. 49-50, podaję za: R. Hauser, op. cit., s. 200.

${ }^{20}$ J. Boć, op. cit., s. 365 i n. „Potrzeba szerszego spojrzenia na prawa i obowiązki podmiotów prawnych, określane prawem administracyjnym, mogłaby być zaspokojona lepiej, gdybyśmy obok pojęcia stosunku prawnego wprowadzili - dające dużo możliwości opisu - pojęcie sytuacji prawnej. Można by nawet pokusić się o wyeliminowanie pojęcia stosunku prawnego [...]. I nie idzie tu wcale o powrót do niektórych koncepcji z początków naszego wieku, odrzucających użyteczność pojęcia stosunku prawnego" (J. Boć, op. cit., s. 367); P. Ochmann, Stosunek administracyjnoprawny w prawie polskim, „Edukacja Prawnicza” 2014, s. 19 i n.

${ }^{21}$ M. Kumela-Romańska, Status administracyjnoprawny, "Samorząd Terytorialny" 2009, $\mathrm{nr} 7$, s. 28-37. „[...] ani stosunek administracyjno-prawny, ani sytuacja administracyjno-prawna nie mają wystarczająco ogólnego charakteru, aby spełnić zadanie polegające na wydobyciu cech położenia prawnego wybranego podmiotu. Jedynie posługiwanie się statusem administracyjno-prawnym pozwala na zachowanie wystarczająco wysokiego stopnia abstrakcyjności. Status administracyjno-prawny pozwala na przedstawienie całokształtu uprawnień i obowiązków podmiotu bez potrzeby sięgania do konstrukcji publicznych praw podmiotowych" (M. Kumela-Romańska, op. cit., s. 37).

${ }^{22}$ J. Boć wskazuje, że stosunek administracyjnoprawny zyskał rangę wręcz niepodważalną, co jednak nie wyklucza, by dla szerszego spojrzenia na prawa i obowiązki podmiotów prawnych określanych prawem administracyjnym stosować pojęcie sytuacji administracyjnoprawnej (J. Boć, op. cit., s. 367).

${ }^{23}$ Zob. np. J. Zimmermann, op. cit., s. 86-87. 


\section{Pojęcie stosunku administracyjnoprawnego}

\subsection{Uwaga wprowadzająca}

Za R. Hauserem, poszukując istotnych cech stosunku administracyjnoprawnego, określa się szczegółowe elementy tego stosunku, tj.: przedmiot stosunku, podmioty stosunku, układy stosunków między podmiotami, a także, jako element dodatkowy, dokonuje się porównań tego stosunku z innymi stosunkami prawnymi ${ }^{24}$. Należy dokonać przeglądu stanowisk w literaturze niemieckiej w powyżej wskazanym zakresie.

\subsection{Geneza pojęcia stosunku administracyjnoprawnego}

Pojęcie stosunku administracyjnoprawnego wywodzi się w prawie niemieckim $\mathrm{z}$ dyskusji ${ }^{25}$ na temat pojęcia publicznych praw podmioto$w_{y} \mathrm{ch}^{26}$. O. Mayer analizował stosunki prawne w prawie administracyjnym, wskazując, że takie stosunki powstają dopiero wtedy, gdy skutek prawny przewidziany $\mathrm{w}$ danym akcie normatywnym, lub nawet $\mathrm{w}$ akcie administracyjnym rzeczywiście już wystąpił w wyniku ziszczenia się

${ }^{24}$ R. Hauser, op. cit., s. 201.

${ }^{25}$ Bardzo szczegółową analizę tej dyskusji przedstawia J. Filipek, Stosunek administracyjnoprawny, Kraków 1968, s. 28-35. Autor cytuje m.in. prace O. Gierkego, C.F. v. Gerbera, G. Jellinka, P. Labanda, A. v. Gneista, a także klasyka niemieckiego prawa administracyjnego O. Mayera. Zob. zwłaszcza G. Jellinek, J. Kersten, System der subjektiven öffentlichen Rechte, durchgesehene und vermehrte Auflage von 1905, Tübingen 2011, a także F. Longchamps, Poglady nauki niemieckiej i austriackiej na publiczne prawa podmiotowe, "Zeszyty Naukowe Uniwersytetu Wrocławskiego. Prawo" 1960, s. 57 i n.

${ }^{26}$ Warto też w tym miejscu przytoczyć krytyczne uwagi pod adresem tej dyskusji sformułowane przez J. Starościaka, Stosunek administracyjnoprawny, w: System prawa administracyjnego, t. 3, pod red. T. Rabskiej, J. Lętowskiego, Warszawa 1978, s. 10: „Bardziej burzliwie, dyskusyjnie zarysowała się tematyka stosunku administracyjnoprawnego w kręgach austriackiej i niemieckiej kultury prawnej. Jako cechy charakteryzujące opracowanie w tym zakresie należy wymienić: a) powiązanie rozważań prawniczych z licznymi teoriami filozofii idealistycznej, powodujące skomplikowanie wywodów, i to wywodów omal wyłącznie z pozycji «obrony» wolnościowych praw obywatela; b) konsekwencją tego punktu wyjścia jest stworzenie konstrukcji «publicznych praw podmiotowych», tj. praw podmiotowych, które musiały być utworzone przez prawo publiczne jako wynik istnienia «naturalnych» praw obywateli; c) szerokie opracowanie tych publicznych praw podmiotowych, a w konsekwencji i stosunków administracyjnoprawnych wewnątrz administracji, jedynie w zakresie układu stosunków między organami scentralizowanej administracji państwa a samodzielnymi, niezależnymi jakoby od państwa, podmiotami administracji zdecentralizowanej". 
odpowiedniego stanu faktycznego ${ }^{27}$. Autor ten dokonał też pierwszej próby klasyfikacji stosunków prawnych, jakie mogą zachodzić pomiędzy władzą publiczną a jednostkami ${ }^{28}$. Po raz pierwszy natomiast pojęciem stosunku administracyjnoprawnego posługiwał się F. Fleiner ${ }^{29}$. Nazywa on stosunki prawne związane z prawem administracyjnym już bezpośrednio stosunkami administracyjnoprawnymi (Verwaltungsrechtsverhältnisse) i w swoim systemie instytucji prawa administracyjnego podnosi pojęcie stosunku administracyjnoprawnego do rangi kluczowego pojęcia z zakresu prawa administracyjnego ${ }^{30}$. Podstawowe znamiona tych stosunków autor sprecyzował przede wszystkim przez przeciwstawienie ich stosunkom prawa prywatnego - z tego punktu widzenia charakteryzuje je, według niego, nierówność podmiotów występujących w nich w charakterze stron stosunku prawnego (możliwość jednostronnego nakładania obowiązków na poddanych), a także bezwzględnie wiążący charakter norm, które je regulują ${ }^{31}$. K. Kormann natomiast wskazał, że stosunki administracyjnoprawne stanowią sumę, kompleks praw i obowiązków między określonymi podmiotami, dając tym samym asumpt do dyskusji prowadzonej w tym zakresie w okresach późniejszych ${ }^{32}$.

Pomimo dużego zróżnicowania poglądów w zakresie prawa publicznego nauka prawa administracyjnego rozwijająca się po II wojnie światowej w Niemczech nawiązuje, generalnie rzecz biorąc, do tradycyjnych poglądów rozwiniętych przez G. Jellinka, O. Mayera, F. Fleinera i innych autorów ${ }^{33}$. Podobnie jak w poprzednim okresie, dyskusja ta w znacznym zakresie oparta była na pojęciu publicznych praw podmiotowych ${ }^{34}$.

Ponadto nowym istotnym elementem stała się dyskusja związana z możliwością wprowadzenia do prawa niemieckiego formy prawnej umowy administracyjnej ${ }^{35}$. Po uchwaleniu w 1949 r. niemieckiej Ustawy Zasadniczej (Grundgesetz) ${ }^{36}$ zaprezentowano potrzebę zwrotu „ku

${ }^{27}$ W. Meger-Hesemann, Die paradigmatische Bedeutung Otto Mayers für die Entwicklung der deutschen Verwaltungsrechtswissenschaft, "Rechtstheorie” 1982, s. 496-497.

${ }^{28}$ O. Mayer, Deutsches Verwaltungsrecht, Bd. 1, Leipzig 1895, s. 105-110.

${ }^{29}$ J. Filipek, op. cit., s. 34-36, 55.

${ }^{30}$ F. Fleiner, Institutionen des deutschen Verwaltungsrechts, Tübingen 1928, s. 149-164.

${ }^{31}$ Ibidem, s. 145, 149 i n.

${ }^{32}$ K. Kormann, System der rechtsgeschäftlichen Staatsakte, Berlin 1910, s. 24 i n., 36-37.

${ }^{33}$ Filipek, op. cit., s. 55.

${ }^{34}$ Współcześnie o publicznych prawach podmiotowych zob. W. Jakimowicz, Publiczne prawa podmiotowe, Kraków 2002.

${ }^{35}$ H. Bauer, Verwaltungsrechtslehre im Umbruch..., s. 304 i n.

${ }^{36}$ Konstytucja Republiki Federalnej Niemiec (Grundgesetz für die Bundesrepublik Deutschland) z 23 V 1949 r. (Bundesgesetzblatt I, s. 1). 
obywatelowi" ${ }^{\prime 37}$. Administracja miała poszukiwać możliwości kontaktu, negocjacji, kooperacji z obywatelem ${ }^{38}$. Paradygmat podporządkowania w ramach hierarchii zastąpiono dążeniem do koncyliacyjnego załatwienia sprawy ${ }^{39}$. Tym samym złamano proklamowaną przez O. Mayera zasadę, że "Państwo nie paktuje z poddanymi", otwierając drogę do wprowadzenia umowy administracyjnej do niemieckiego systemu prawnych form działania administracji ${ }^{40}$. Należy podkreślić, że zmiana postrzegania pojęcia stosunku administracyjnoprawnego $\mathrm{w}$ kierunku objęcia tym pojęciem takiej formy jak umowa administracyjna, była w Niemczech procesem długotrwałym. Ponadto, jak wynika z cytowanej obszernej literatury, towarzyszyła mu burzliwa i bardzo owocna dyskusja.

Przykładowo w tym okresie K.E. Turegg podniósł, że stosunki administracyjnoprawne stanowią określony rezultat prawny, zawarty z reguły w akcie administracyjnym, który określona norma prawna przywiązuje

\footnotetext{
${ }^{37}$ F. Hase, op. cit., s. 458.

${ }^{38}$ Ibidem.

${ }^{39}$ Ibidem.
}

${ }^{40} \mathrm{H}$. Bauer, § 36 Verwaltungsverträge, w: Grundlagen des Verwaltungsrecht, Bd. 2: Informationsordnung, Verwaltungsverfahren, Handlungsformen, Hrsg. von W. Hoffmann-Riem, E. Schmidt-Assmann, A. Voßkuhle, München 2012, s. 1255-1387; M. Bullinger, Vertrag und Verwaltungsakt, Stuttgart 1962; U. Di Fabio, System der Handlungsformen und Fehlerfolgenlehre, w: Wandel der Handlungsformen im öffentlichen Recht. 31. Tagung der Wissenschaftlichen Mitarbeiterinnen und Mitarbeiter der Fachrichtung "Öffentliches Recht", Hrsg. von K. Becker-Schwarze, Bremen 1991, s. 47 i n.; D. Ehlers, Die Handlungsformen bei der Vergabe von Wirtschaftssubventionen, "Verwaltungsarchiv" 1983, s. 112-132; idem, Verwaltung in Privatrechtsform, Berlin 1984; E. Forsthoff, Lehrbuch des Verwaltungsrechts, Allgemeiner Teil, Bd. 1, München 1973; E. Gurlit, Verwaltungsvertrag und Gesetz. Eine vergleichende Untersuchung zum Verhältnis von vertraglicher Bindung und staatlicher Normsetzungsautorität, Tübingen 2000; W. Henke, Das Recht der Wirtschaftssubventionen als öffentliches Vertragsrecht, Tübingen 1979; H.G. Henneke, 30 Jahre LVwG, 20 Jahre VwVfG - Stabilität und Flexibilität des Verwaltungshandelns, „Die Öffentliche Verwaltung” 1997, s. 768 i n.; F. Ossenbühl, Die Handlungsformen der Verwaltung, "Juristische Schulung" 1979, s. 681-687; W. Rüfner, Formen öffentlicher Verwaltung im Bereich der Wirtschaft: Untersuchungen zum Problem der leistenden Verwaltung, Berlin 1967; E. Schmidt-Assmann, Die Lehre von den Rechtsformen..., s. 533, 539 i n.; Z. Giacometti, Allgemeine Lehren der rechtsstaatlichen Verwaltungsrecht, Zürich 1960, s. 95; B. Tanneberg, Die Zweistufentheorie, Berlin 2011, s. 71 i n.; H. Schmitz, Die Verträge sollen sicherer werden - zur Novellierung der Vorschriften über den öffentlich-rechtlichen Vertrag, "Deutsches Verwaltungsblatt” 2005, s. 18 i n.; H. Pünder, Kooperation statt Konfrontation Zur der Kontrakte zwischen Politik und Verwaltung im Rahmen des Neuen Steuerungsmodell, "Die Öffentliche Verwaltung" 1998, z. 2, s. 63-71; F. Mayer, Allgemeines Verwaltungsrecht, Stuttgart 1972, s. 96 i n.; T. Öhlinger, Allgemeines Verwaltungsrecht, Stuttgart 1972, s. 11 i n.; H.U. Erichsen, W. Martens, Das Verwaltungshandeln, w: idem, Allgemeines Verwaltungsrecht, Berlin-New York 1977, s. 212 i n. 
do konkretnego stanu faktycznego ${ }^{41}$. W tym wypadku, według autora, publiczne prawa podmiotowe obywateli wynikają z obowiązujących przepisów prawnych i oznaczają uprawnienie, na podstawie którego dany podmiot, $\mathrm{w}$ interesie własnym lub cudzym, może dochodzić ochrony swojej pozycji prawnej: żądać od organów administracji publicznej określonych działań (np. świadczeń społecznych) lub zaniechań (np. unieważnienia obowiązku nałożonego bezpodstawnie) albo powodować zawiązanie lub współkształtować razem z władzą pewne stosunki prawne (przypadki wydawania aktów administracyjnych na wniosek strony $)^{42}$. Z kolei R. Nebinger stanął na stanowisku, że podstawową cechą stosunku administracyjnoprawnego jest nierówność stron, co wynika z faktu, że państwo dysponuje władczymi środkami działania $^{43}$. H.J. Wolff wskazał, że stosunki administracyjnoprawne dotyczą wzajemnych obowiązków i uprawnień stron związanych z określonym działaniem, znoszeniem lub zaniechaniem ${ }^{44}$. H.H. Rupp z kolei wiele uwagi poświęcił administracyjnoprawnym stosunkom wewnętrznym, stając na stanowisku, że obejmują one stosunki łączące urzędników i organy państwa z państwem jako takim ${ }^{45}$. Wreszcie klasyk prawa administracyjnego E. Forsthoff uznał, że w przypadku stosunku administracyjnoprawnego organy administracji publicznej występują wobec jednostek w charakterze władzy państwowej, jednostronnie rozkazują$\operatorname{cej}^{46}$. Jednocześnie uznał, że umowy administracyjne są dopuszczalne zawsze wtedy, gdy ustawa nie przewiduje wyraźnie władczych form działania administracji i gdy nie pozostają one w sprzeczności z istotac określonych funkcji państwa ${ }^{47}$. Tym stwierdzeniem wniósł istotny wkład w kształtowanie się w niemieckiej doktrynie prawa publicznego zasady swobody wyboru prywatnoprawnej formy działania ${ }^{48}$.

${ }^{41}$ K.E. Turegg, Lehrbuch des Verwaltungsrecht, Berlin 1956, s. 89 i n., podaję za: J. Filipek, op. cit., s. 55-56.

${ }^{42}$ K.E. Turreg, op. cit., s. 56 i n.

${ }^{43}$ R. Nebinger, Verwaltungsrecht (Allgemeiner Teil), Stuttgart 1949, s. 254 i n.

${ }^{44}$ H.J. Wolff, O. Bachof, R. Stober, Verwaltungsrecht I, München 1994, s. 387 i n.

${ }^{45}$ H.H. Rupp, Grundfragen der heutigen Verwaltungsrechtslehre: Verwaltungsnorm und Verwaltungsrechtsverhältnis, Tübingen 1965, s. 16, 19-101.

${ }^{46}$ E. Forsthoff, op. cit., s. 49, 124-141, 146-149 i n.

${ }^{47}$ Ibidem, s. 208 i n.

${ }^{48}$ Szerzej zob. P. Sancewicz, Teoria dwóch stopni w doktrynie niemieckiego prawa publicznego, "Studia Prawa Publicznego" 2013, nr 4, s. 142 i n.; idem, Swoboda wyboru formy prawnej działania administracji w polskiej i niemieckiej doktrynie prawa publicznego, "Studia Prawa Publicznego" 2019, nr 3, s. 93-116. 
Na gruncie austriackim L. Adamovich opiera koncepcję stosunku administracyjnoprawnego również na prawach i obowiązkach uczestniczącej w nim każdorazowo administracji państwowej ${ }^{49}$. Jej kompetencjom (Befugnisse) odpowiada, według niego, po stronie jednostek obowiązek podporządkowania się zarządzeniom, jakie administracja do nich kieruje ${ }^{50}$. Autor wyodrębnia następnie wśród stosunków prawnych stosunki prawne dotyczące korzyści prawnych jednostki (rechtliche Vorteile) i stosunki prawne dotyczące ich obowiązków (rechtliche Nachteile) ${ }^{51}$.

Ponowne ożywienie dyskusji nad pojęciem stosunku administracyjnoprawnego można odnotować w okresie po 1989 r. - czasie przełomu społeczno-politycznego związanego ze zjednoczeniem Niemiec (Wende). Wtedy m.in. powstały cytowane powyżej prace H. Bauera, R. Gröschnera, J. Pietzckera, T. von Danwitza ${ }^{52}$, a także liczne prace habilitacyjne ${ }^{53}$, które w większym lub mniejszym stopniu koncentrowały się na analizie różnorodnych stosunków administracyjnoprawnych w prawie niemieckim.

\subsection{Poglądy współczesnej niemieckiej doktryny na temat pojęcia stosunku administracyjnoprawnego}

Obecnie stosunek administracyjnoprawny stanowi ugruntowane pojęcie w doktrynie niemieckiego prawa publicznego ${ }^{54}$. Jednakże ze względu na braki w kodyfikacji niemieckiego materialnego prawa administracyjnego jest on unormowany jedynie rudymentarnie ${ }^{55}$. Co ciekawe, ogólne

\footnotetext{
${ }^{49}$ L. Adamovich, Handbuch des österreichischen Verwaltungsrecht, Wien 1954, s. 77 i n.

${ }^{50}$ Ibidem.

${ }^{51}$ Ibidem.

52 T. von Danwitz, Zu Funktion und Bedeutung der Rechtsverhältnislehre, "Die Verwaltung”
} 1997, z. 1-4, s. 339-363.

${ }^{53}$ P.M. Huber, Konkurrenzschutz im Verwaltungsrecht: Schutzanspruch und Rechtsschutz bei Lenkungs- und Verteilungsentscheidungen der öffentlichen Verwaltung, Tübingen 1991; M. Schmidt-Preuß, Kollidierende Privatinteressen im Verwaltungsrecht. Das subjektive öffentliche Recht im multipolaren Verwaltungsrechtsverhältnis, Berlin 1992; H. Bauer, Die Bundestreue. Zugleich ein Beitrag zur Dogmatik des Bundesstaatsrechts und zur Rechtsverhältnislehre, Tübingen 1991; R. Gröschner, Das Überwachungsrechtsverhältnis - Wirtschaftsüberwachung in gewerbepolizeirechtlicher Tradition und wirtschaftsverwaltungsrechtlichem Wandel, Tübingen 1992; M. Schulte, Schlichtes Verwaltungshandeln. Verfassungs- und verwaltungsrechtsdogmatische Strukturüberlegungen am Beispiel des Umweltrechts, Tübingen 1995.

${ }^{54}$ R. Stober, op. cit., Nb. 36.

${ }^{55}$ Ibidem. 
unormowanie stosunku administracyjnoprawnego dotyczy wyłącznie stosunku prawnopodatkowego ${ }^{56}$. W niemieckiej Ordynacji podatkowej uregulowano podmioty, przedmiot, powstanie i wygaśnięcie stosunku prawnopodatkowego. Tym samym rozważania obejmują nie tylko niemiecką doktrynę prawa administracyjnego, ale całą naukę prawa publicznego.

Stosunek administracyjnoprawny dotyczy stosunków z zakresu prawa administracyjnego i jest zawierany między co najmniej dwoma podmiotami prawa ${ }^{57}$. Podstawę stosunku administracyjnoprawnego stanowią stosunki prawne między obywatelem a podmiotem administracji ${ }^{58}$. Stosunki prawne muszą wynikać z zastosowania norm prawnych w odniesieniu do konkretnego stanu faktycznego ${ }^{59}$.

W prawie niemieckim stosunek administracyjnoprawny może powstać na podstawie aktów prawnych powszechnie obowiązujących (ustawa, rozporządzenie, statut), na podstawie aktu administracyjnego, umowy administracyjnej, albo nawet czynności faktycznej ${ }^{60}$. W podobny sposób stosunki administracyjnoprawne mogą być zmieniane albo znoszone $^{61}$. Przykładowo podstawą stosunku administracyjnoprawnego nawiązanego w formie czynności faktycznej może być stosunek

${ }^{56}$ Ibidem.

${ }^{58}$ Ibidem.

${ }^{59}$ Ibidem; H. Maurer, Verwaltungsrechtsverhältnis, w: H. Maurer, Ch. Waldhoff, Allgemeines Verwaltungsrecht, München 2017, s. 191, Nb. 18.

${ }^{60}$ H. Maurer, op. cit., s. 192, Nb. 20; podobnie H. Bauer, Verwaltungsrechtslehre im Umbruch..., s. 318-320 i n. Wątpliwości budzi powstanie stosunku administracyjnoprawnego na podstawie umowy administracyjnej. O powyższym przesądził jednak wprost ustawodawca niemiecki. Przykładów na powyższe dostarcza niemiecka definicja legalna umowy administracyjnej, wskazana w $\S 54$ federalnej ustawy o postępowaniu administracyjnym (Verwaltungsverfahrensgesetz, ustawa z dnia 25 V 1976 r., Bundesgesetzblatt I, s. 153): „stosunek prawny z zakresu prawa publicznego może być w drodze umowy zawarty, zmieniony lub zniesiony (umowa publicznoprawna), o ile nie stoją temu na przeszkodzie przepisy prawa. W szczególności organ administracyjny może zamiast wydawania aktu administracyjnego zawrzeć umowę publicznoprawną z podmiotem, do którego kierowany byłby akt administracyjny" (Ein Rechtsverhältnis auf dem Gebiet des öffentlichen Rechts kann durch Vertrag begründet, geändert oder aufgehoben werden (öffentlich-rechtlicher Vertrag), soweit Rechtsvorschriften nicht entgegenstehen. Insbesondere kann die Behörde, anstatt einen Verwaltungsakt zu erlassen, einen öffentlich-rechtlichen Vertrag mit demjenigen schließen, an den sie sonst den Verwaltungsakt richten würde), tłum. w: B. Dolnicki, Umowa publicznoprawna w prawie niemieckim, „Państwo i Prawo" 2001, z. 3, s. 79.

${ }^{61}$ H. Maurer, op. cit., s. 193, Nb. 20. 
korzystania z urządzeń o charakterze użyteczności publicznej (z prawami i obowiązkami zarówno po stronie gminy, jak i użytkownika) ${ }^{62}$.

Warto w tym miejscu zwrócić uwagę, że dla przedstawicieli współczesnej niemieckiej doktryny stosunek administracyjnoprawny nie jest definiowany jako w pierwszej kolejności zakładający władcze działanie przez administrację publiczną wobec podmiotów jej podporządkowanych. Taka definicja stosunku administracyjnoprawnego została utrwalona w polskiej doktrynie przez J. Starościaka i J. Filipka ${ }^{63}$ i do dzisiaj znajduje szerokie poparcie. Równocześnie jednak już J. Starościak rozważał potrzebę odejścia od paradygmatu nierówności stron stosunku administracyjnoprawnego w każdym przejawie tego stosunku ${ }^{64}$. Według autora nie oznacza to jednak nastąpienia sytuacji odwrotnej - całkowitego odwrócenia tej cechy stosunku administracyjnoprawnego we wszystkich jego przejawach, służy jednak do zróżnicowania poglądów na tę cechę w zależności od okoliczności, które stosunek ten obejmuje ${ }^{65}$. Jak wywodzi H. Bauer, stosunek administracyjnoprawny znajduje zastosowanie do stosunków prawnych między państwem a obywatela$\mathrm{mi}^{66}$. Równocześnie, $\mathrm{w}$ wielu miejscach, znajduje on podstawę prawną w niemieckiej Ustawie Zasadniczej (Grundgesetz) ${ }^{67}$. Do istoty demokratycznego państwa prawnego należy to, że wszystkie stosunki między państwem i obywatelami mają formę stosunków prawnych ${ }^{68}$. O nadrzędności w stosunkach między państwem, względnie administracją publiczną a obywatelem można mówić wyłącznie wtedy, gdy sytuacja ta wynika z powszechnie obowiązujących przepisów prawa ${ }^{69}$. Dogmatyczna konstrukcja stosunku administracyjnoprawnego stawia obywatela $\mathrm{w}$ pozycji aktywnej $\mathrm{w}$ odniesieniu do administracji, aktywna pozycja obywatela wynika zaś bezpośrednio z wielu przepisów niemieckiej Ustawy Zasadniczej ${ }^{70}$. Powyższe ułatwia ustanawianie kooperacyjnych struktur, nie tracąc jednocześnie z oczu klasycznych konstrukcji podporządkowania i nadrzędności ${ }^{71}$. H. Hase zakwestionował, że stosunek

\footnotetext{
${ }^{62}$ Ibidem.

${ }^{63}$ J. Filipek, op. cit., s. $98-99$ i n., 118 i n., 128 i n.

${ }^{64}$ J. Starościak, op. cit., s. $14-15$ i n.

${ }^{65}$ Ibidem.

${ }^{66}$ H. Bauer, Verwaltungsrechtslehre im Umbruch..., s. 317.

${ }^{67}$ Ibidem.

${ }^{68}$ Ibidem.

${ }^{69}$ Ibidem, s. 318 i n.

${ }^{70}$ Ibidem.

${ }^{71}$ Ibidem; podobnie T. von Danwitz, op. cit., s. 341 i n.
} 
administracyjnoprawny jest ściśle związany z autorytatywnym działaniem, podczas gdy, według niego, jest on właśnie szczególnie związany z pozbawionym władczości dyskursem i stoi w szczególnej bliskości do równoprawnych stosunków kooperacyjnych ${ }^{72}$.

Stosunki administracyjnoprawne to takie stosunki, które dotyczą norm prawa administracyjnego, jak doprecyzowuje F. Hase, które znajdują uzasadnienie w normach prawa administracyjnego ${ }^{73}$. Według tego autora przykładami stosunków administracyjnoprawnych w prawie administracyjnym są kompleksowe relacje, które znajdują uzasadnienie w przepisach szczególnego prawa administracyjnego, w którym w centrum zainteresowania stoi uprawnienie lub obowiązek - przykładami są tu stosunek urzędniczy, stosunek przyznawania i udzielania pomocy publicznej, stosunek prawnopodatkowy, stosunek socjalny ${ }^{74}$. H. Maurer z kolei zakreśla zakres stosunku administracyjnoprawnego niezwykle szeroko: przedmiotem tego stosunku może być mianowicie wszystko, co jest prawem dozwolone ${ }^{75}$.

Według H. Bauera stosunek administracyjnoprawny nie jest zdeterminowany poszczególnymi prawami i obowiązkami, lecz raczej przez wiązkę praw i obowiązków, a także związkami między nimi ${ }^{76}$. Połączenie poszczególnych praw i obowiązków w zbiorczą całość prowadzi do powstania złożonego stosunku administracyjnego (Gesamtverhältnis) ${ }^{77}$. Tym samym pojęcie stosunku administracyjnoprawnego umożliwia złożoną analizę wszystkich zdarzeń wpływających na pozycję prawną jednostki, a mianowicie wszystkich "dodatkowych" praw i obowiązków, takich jak informowanie, doradzanie, współdziałanie ${ }^{78}$.

Teoretyczna konstrukcja stosunku administracyjnoprawnego pozwala zastosować całościowe spojrzenie na stosunek administracyjnoprawny

${ }^{72}$ F. Hase, op. cit., s. 459 i n.

${ }^{73}$ Ibidem; podobnie H. Maurer, op. cit., s. 191, Nb. 18.

${ }^{74}$ F. Hase, op. cit., s. 455 i n. Istnieją różne dalsze możliwości podziału stosunków administracyjnoprawnych - np.S. Detterbeck proponuje podział na stosunki krótkotrwałe i trwałe (S. Detterbeck, op. cit., s. 126-127, Nb. 414; podobnie H. Maurer, op. cit., s. 193, $\mathrm{Nb} .21-23)$. Warto jednak w tym miejscu wskazać, że autorzy niemieccy, w przeciwieństwie do polskiej doktryny prawa, analizują rodzaje stosunków administracyjnoprawnych raczej na marginesie głównego toku rozważań.

${ }^{75}$ H. Maurer, op. cit., s. 193, Nb. 21.

${ }^{76}$ H. Bauer, Verwaltungsrechtslehre im Umbruch..., s. 318 i n.; podobnie H. Hase, op. cit., s. 461 i n.

${ }^{77}$ H. Bauer, Verwaltungsrechtslehre im Umbruch...; podobnie R. Gröschner, Vom Nutzen..., s. 333 i n.

${ }^{78}$ H. Bauer, Verwaltungsrechtslehre im Umbruch... 
między administracją publiczną a obywatelem, nie koncentruje się zaś na poszczególnych zjawiskach prawnych (np. konkretnych prawnych formach działania administracji ${ }^{79}$.

Stosunek administracyjnoprawny dopuszcza ponadto możliwość ujęcia relacji wielostronnych, co oznacza takie stosunki prawne, w których uczestniczą nie dwa, lecz trzy lub więcej podmioty prawa ${ }^{80}$.

\section{Przyszłość pojęcia stosunku administracyjnoprawnego}

Przedstawiciele niemieckiej doktryny zauważają pewien deficyt wypływający z faktu, że niemiecka administracja nie potrafi w zadowalający sposób sprostać zadaniom wynikającym zarówno z niemieckiej Ustawy Zasadniczej, jak i prawa unijnego ${ }^{81}$. Obecne podejście nie uwzględnia bowiem w stopniu wystarczającym tego, że współczesna administracja powinna być nastawiona na współpracę, współoddziaływanie, a także na działania na zasadach subsydiarności (współodpowiedzialności) ${ }^{82}$. Nie można przeoczyć faktu, że współczesna administracja nie koncentruje się na działaniach w formach władczych, lecz na efektywnej realizacji zadań publicznych, głównie z zakresu administracji świadczącej, co znajduje egzemplifikację szczególnie w prawie socjalnym oraz $\mathrm{w}$ prawie ochrony środowiska ${ }^{83}$.

R. Stober uznaje stosunek administracyjnoprawny za instytucję, która zasługuje na to, aby uzyskać dominującą rolę w prawie administracyjnym może stanowić podstawę nowej systematyki prawa administracynego ${ }^{84}$. W niemieckiej doktrynie pojawiają się poglądy, zgodnie z którymi stosunek administracyjnoprawny stanowi "organizm”, który znaczy coś innego i coś więcej niż same odizolowane jego części, co w tym przypadku sprowadza się do możliwości całościowego ujmowania kompleksowych problemów prawnych ${ }^{85}$. Tym samym pojawiają się też poglądy, zgodnie z którymi cały system prawny stanowi system stosunków prawnych ${ }^{86}$.

${ }^{79}$ H. Bauer, Verwaltungsrechtslehre im Umbruch...; podobnie R. Gröschner, Vom Nutzen..., s. 336 i n.

${ }^{80} \mathrm{H}$. Bauer, Verwaltungsrechtslehre im Umbruch...; podobnie R. Gröschner, Vom Nutzen..., s. 333 i n.

${ }^{81}$ R. Stober, op. cit., Nb. 37.

${ }^{82}$ Ibidem.

${ }^{83}$ Ibidem.

${ }^{84}$ Ibidem, Nb. 38.

${ }^{85}$ Ibidem.

${ }^{86}$ Ibidem. 
Niemiecka doktryna prawa publicznego rozważała nawet, czy stosunek administracyjnoprawny nie powinien zastąpić pojęcia aktu administracyjnego jako podstawa dogmatyki prawa publicznego ${ }^{87}$. Wskazywano również na mankamenty pojęcia prawnych form działania. Zostały one słusznie określone jako ujęcia momentalne (Momentaufnahmen) ${ }^{88}$, które nie nadają się do opisywania złożonych sytuacji prawnych. Stosunek administracyjnoprawny, jak już wskazano powyżej, obejmuje zaś zestaw praw i obowiązków podmiotu administrowanego, a także kompleks czynności podejmowanych przez organy administracji publicznej. Nasuwa się tu jednak wniosek, że niemiecka doktryna prawa publicznego nie wyróżnia pojęcia sytuacji administracyjnoprawnej, utożsamiając ją raczej właśnie z pojęciem stosunku administracyjnoprawnego.

W tym miejscu należy postawić pytanie, co wynika z ustaleń niemieckiej nauki dla nauki polskiej. Niemieccy uczeni zaakceptowali, że stosunek administracyjnoprawny może mieć zastosowanie do stosunków konsensualnych i że sama jego idea oparta jest na kooperacji, dialogu oraz współdziałaniu w realizacji zadań publicznych z podmiotami administrowanymi. Już od dawna natomiast niemiecka nauka odeszła od paradygmatu władczości, podporządkowania w tym zakresie. Nauka polska powinna z takiego podejścia wyciągnać wnioski - zwłaszcza przy ostatnio wzmożonej dyskusji nad wprowadzeniem umowy administracyjnej do polskiego porządku prawnego ${ }^{89}$. Przy wprowadzeniu ko-

${ }^{87}$ H. Maurer, op. cit., s. 195, Nb. 26.

${ }^{88}$ O. Bachof, Die Dogmatik des Verwaltungsrechts vor den Gegenwartsaufgaben der Verwaltung, Berichte und Diskussionen auf der Tagung der Vereinigung der Deutschen Staatsrechtslehrer in Regensburg vom 29. September bis 2. Oktober 1971, Berlin 1972, s. 193-218.

${ }^{89}$ A. Krawczyk, Umowa administracyjna w demokratycznym państwie prawnym - w poszukiwaniu modelu regulacji prawnej, "Zeszyty Naukowe Sądownictwa Administracyjnego" 2017, nr 6, s. 7-25; A. Ostrowska, Koncepcja umowy administracyjnej na przykładzie umowy o dotację w świetle polskich i zagranicznych regulacji, „Prawo Budżetowe Państwa i Samorządu" 2018, nr 3, s. 9-27; J. Trzewik, B. Kuś, Zastosowanie konstrukcji prawnej umowy w administracji publicznej, "Studia Iuridica Lublinensia” 2017, nr 3, s. 65-76; Z.H. Stawińska, Legitymacja skargowa na gruncie art. 50 § 1 p.p.s.a. w przypadku wprowadzenia do polskiego porządku prawnego umów administracyjnych, subordynacyjnych na wzór rozwiązań z prawa niemieckiego z § 54 VwVfG, „Kwartalnik Prawo, Społeczeństwo, Ekonomia” 2019, nr 1, s. 29-38; Reforma prawa o postępowaniu administracyjnym. Raport zespolu eksperckiego, Warszawa 2016, s. 144-147, 458-464, http://www.nsa.gov.pl/archiwum-aktualnosci/ uzupelniony-raport-ekspercki-nt-reforma-prawa-o-postepowaniu-administracyjnym,news,27,327.php?p=7 (dostęp: 5 III 2020); L. Staniszewska, Zagadnienia konstrukcyjne umów publicznoprawnych, "Studia Prawa Publicznego" 2019, nr 3, s. 142-143 i n. Szerzej na ten temat zob. P. Sancewicz, Umowa jako prawna forma działania administracji publicznej 
operacyjnej prawnej formy działania, jaką jest umowa administracyjna, utrzymanie obowiązującego paradygmatu jednostronnego działania może być bowiem problematyczne. Tym samym, gdy umowa administracyjna stanie się elementem polskiego systemu prawnego, pojęcie stosunku administracyjnoprawnego będzie musiało ulec pewnej ewolucji, tak aby zostały w nim ujęte stosunki kooperacyjne, wielostronne. Należy podkreślić, że w przypadku braku takiej rewizji pojęcie stosunku administracyjnoprawnego może utracić swoją podstawową funkcję, tj. przydatność w procesach poznawania, badania, stosowania i nauczania prawa.

\section{Podsumowanie}

Przeprowadzony przegląd niemieckiej literatury skłania do wniosku, że poglądy niemieckiej doktryny prawa publicznego na istotę stosunku administracyjnoprawnego są $\mathrm{w}$ zasadzie jednolite. Powyższe dotyczy okresu wcześniejszego, w którym powszechnie przyjmowano, że stosunek administracyjnoprawny charakteryzuje się nierównorzędnością stron tego stosunku. Potem, w związku z wprowadzeniem do niemieckiego systemu prawnego umowy administracyjnej, poglądy na istotę stosunku administracyjnoprawnego uległy ewolucji. Współcześnie, pomimo pewnych sporów, autorzy niemieccy uważaja, że stosunek administracyjnoprawny stanowi użyteczne narzędzie do analizy ogółu praw i obowiązków w kompleksowych relacjach prawnych, a także podnoszą przydatność pojęcia stosunku administracyjnoprawnego w układach kooperacyjnych. Współcześni badacze niemieccy, inaczej niż polscy, nie wyróżniając pojęcia sytuacji administracyjnoprawnej, stoją na stanowisku, że w ramach procesów modernizacyjnych administracji pojęcie stosunku administracyjnoprawnego może służyć do rozwiązywania kompleksowych problemów prawnych.

Powyżej wskazane odkrycia niemieckich badaczy mogą stanowić istotną inspirację dla polskiej doktryny prawa publicznego, szczególnie w kontekście prac nad projektem umowy administracyjnej w prawie polskim. Być może trzeba będzie w przyszłości rozważyć, czy wprowadzenie do polskiego systemu prawnego umowy administracyjnej nie spowoduje konieczności rewizji zastanych w doktrynie prawa publicznego

w polskiej i niemieckiej doktrynie prawa publicznego, „Studia Prawa Publicznego” 2019, nr 1, s. 55 i n. 
pojęć, w szczególności stosunku administracyjnoprawnego. Powyższa kwestia wymaga z pewnością dalszych badań. Należy przy tym liczyć na to, że podobnie jak w Niemczech, dyskusja naukowa w tym zakresie będzie bardzo owocna.

Polscy badacze (np. J. Boć) upatrują możliwości opisywania kompleksowych konstrukcji prawnych za pomocą pojęcia stosunku administracyjnoprawnego w jednoczesnym lub uzupełniającym korzystaniu z koncepcji sytuacji administracyjnoprawnej - pamiętając przy tym, że oba pojęcia są wyraźnie oddzielane. Należy poddać pod rozwagę, czy tych samych lub lepszych efektów nie można osiągnąć znacznie prościej, a mianowicie poprzez modyfikację rozumienia w doktrynie pojęcia stosunku administracyjnoprawnego, bardziej odpowiedniego do analizy układów kooperacyjnych w administracji.

\section{ADMINISTRATIVE RELATIONSHIP IN THE GERMAN DOCTRINE OF PUBLIC LAW}

\section{Su m mary}

The notion of the administrative-legal relationship is the basis of the dogmatics of Polish administrative law. Over the years, the doctrinal framework of this concept has been established by the doctrine of public law. At the same time, an extremely fruitful dogmatics discussion about this concept both in German law and practice has taken place. Therefore, the article attempts to present discoveries of the German doctrine of public law in this area.

The review of the German literature conducted in the article shows that, despite some disputes, the German authors currently believe that the administrative-legal relationship is a useful tool for the analysis of rights and obligations in comprehensive legal relations, as well as cooperative frameworks. Contemporary German scholars, who do not distinguish the concept of a legal situation, unlike in Poland, believe that as part of the modernization processes in administration, the concept of the administrative-legal relationship can be used to solve complex legal issues.

The above-mentioned discoveries made by German scholars could act as significant inspiration for the Polish doctrine of public law, especially in the context of the draft to introduce an administrative agreement into Polish law. Of particular importance here is the fact that in Germany there is a different system of the legal forms of administration activity, of which an administrative agreement is a vital component.

It is indicated in the paper that Polish scholars see the possibility of describing complex legal constructions by the notion of the administrative-legal relationship in the simultaneous or complementary use of the concept of the administrative-legal situation. One should consider whether the same or better effects cannot be 
achieved much more easily, namely by modifying the understanding in the doctrine of the notion of administrative-legal relationship, more appropriate to the analysis of cooperative frameworks in administration.

Keywords: administrative-legal relationship - legal forms of administrative activity - administrative procedure - public subjective rights - administrative contract

\section{LITERATURA}

Adamovich L., Handbuch des österreichischen Verwaltungsrecht, Wien 1954.

Bauer H., Die Bundestreue. Zugleich ein Beitrag zur Dogmatik des Bundesstaatsrechts und zur Rechtsverhältnislehre, Tübingen 1991.

Bauer H., Entwicklungslinien der Vertragsrechtslehre, w: Grundlagen des Verwaltungsrecht, Bd. 2: Informationsordnung, Verwaltungsverfahren, Handlungsformen, Hrsg. von W. Hoffmann-Riem, E. Schmidt-Assmann, A. Voßkuhle, München 2012.

Bauer H., Verwaltungsrechtslehre im Umbruch? Rechtsformen und Rechtsverhältnisse als Elemente einer zeitgemäßen Verwaltungsrechtsdogmatik, "Die Verwaltung” 1992, z. 1-4.

Bauer H., Zurnotwendigen Entwicklung eines Verwaltungskooperationsrechts - Statement, w: G.F. Schuppert (red.), Jenseits von Privatisierung und "schlankem" Staat: Verantwortungsteilung als Schlüsselbegriff eines sich verändernden Verhältnisses von öffentlichem und privatem Sektor, Baden-Baden 1999.

Boć J., Pojęcie stosunku administracyjnoprawnego, w: Prawo administracyjne, pod red. J. Bocia, Wrocław 2010.

Cieślak Z., Stosunek administracyjnoprawny, w: Prawo administracyjne, pod red. Z. Niewiadomskiego, Warszawa 2007.

Danwitz von T., Zu Funktion und Bedeutung der Rechtsverhältnislehre, „Die Verwaltung” 1997, z. 1-4.

Dawidowicz W., Polskie prawo administracyjne, Warszawa 1978.

Detterbeck S., Allgemeines Verwaltungsrecht mit Verwaltungsprozessrecht, München 2016.

Dolnicki B., Umowa publicznoprawna w prawie niemieckim, „Państwo i Prawo” 2001, z. 3.

Duniewska Z., Stosunek administracyjnoprawny. Sytuacja administracyjnoprawna, w: Z. Duniewska, B. Jaworska-Dębska, M. Kasiński, E. Olejniczak-Szałowska, M. Stahl, Prawo administracyjne. Pojęcia, instytucje, zasady w teoriii orzecznictwie, pod red. M. Stahl, Warszawa 2013.

Filipek J., Stosunek administracyjnoprawny, Kraków 1968.

Fleiner F., Institutionen des deutschen Verwaltungsrechts, Tübingen 1920.

Forsthoff E., Lehrbuch des Verwaltungsrecht. Allgemeiner Teil, Bd. 1, München-Berlin 1950.

Geburczyk F., Zjawisko proceduralizacji w prawie administracyjnym a kierunki ewolucji procedury administracyjnej, Warszawa 2019.

Gröschner R., Das Überwachungsrechtsverhältnis - Wirtschaftsüberwachung in gewerbepolizeirechtlicher Tradition und wirtschaftsverwaltungsrechtlichem Wandel, Tübingen 1992. 
Gröschner R., Vom Nutzen des Verwaltungsrechtsverhältnis, „Die Verwaltung” 1997, z. 1-4.

Hase F., Das Verwaltungsrechtsverhältnis. Überlegungen zu einem Grundbegriff des Öffentlichen Rechts, "Die Verwaltung” 2005, z. 1-4.

Hauser R., Pojęcie i znaczenie stosunku administracyjnoprawnego, w: R. Hauser, Z. Niewiadomski, A. Wróbel (red.), System prawa administracyjnego, t. 1: Instytucje prawa administracyjnego, Warszawa 2015.

Huber P.M., Konkurrenzschutz im Verwaltungsrecht: Schutzanspruch und Rechtsschutz bei Lenkungs- und Verteilungsentscheidungen der öffentlichen Verwaltung, Tübingen 1991.

Jakimowicz W., Publiczne prawa podmiotowe, Kraków 2002.

Jellinek G., Kersten J., System der subjektiven öffentlichen Rechte, durchgesehene und vermehrte Auflage von 1905, Tübingen 2011.

Kormann K., System der rechtsgeschäftlichen Staatsakte, Berlin 1910.

Kumela-Romańska M., Status administracyjnoprawny, "Samorząd Terytorialny” 2009, nr 7.

Leoński Z., Stosunek administracyjnoprawny, w: idem, Zarys prawa administracyjnego, Warszawa 2006.

Longchamps F., Poglady nauki niemieckiej i austriackiej na publiczne prawa podmiotowe, "Zeszyty Naukowe Uniwersytetu Wrocławskiego. Prawo" 1960.

Maurer H., Ogólne prawo administracyjne (Allgemeines Verwaltungsrecht), tłum. i red. K. Nowacki, Wrocław 2003.

Maurer H., Verwaltungsrechtsverhältnis, w: H. Maurer, Ch. Waldhoff, Allgemeines Verwaltungsrecht, München 2017.

Mayer O., Deutsches Verwaltungsrecht, Bd. 1, Leipzig 1895.

Nebinger R., Verwaltungsrecht (Allgemeiner Teil), Stuttgart 1949.

Ochendowski E., Prawo administracyjne. Czesść ogólna, Torun 2009.

Ochmann P., Stosunek administracyjnoprawny w prawie polskim, „Edukacja Prawnicza” 2014.

Peters A., Nebenpflichten im Verwaltungsrechtsverhältnis?, "Die Verwaltung" 2002, s. $177-221$.

Pietzker J., Das Verwaltungsrechtsverhältnis - archimedischer Punkt oder Münchhausens Zopf?, „Die Verwaltung” 1997, z. 1-4, s. 281-299.

Rupp H.H., Grundfragen der heutigen Verwaltungsrechtslehre, Tübingen 1965.

Sancewicz P., Swoboda wyboru formy prawnej działania administracji w polskiej i niemieckiej doktrynie prawa publicznego, "Studia Prawa Publicznego” 2019, nr 3.

Sancewicz P., Teoria dwóch stopni w doktrynie niemieckiego prawa publicznego, "Studia Prawa Publicznego" 2013, nr 4.

Sancewicz P., Umowa jako prawna forma działania administracji publicznej w polskiej i niemieckiej doktrynie prawa publicznego, „Studia Prawa Publicznego” 2019, nr 1.

Schmidt-Aßmann E., Das allgemeine Verwaltungsrecht als Ordnungsidee und System: insbesondere zur Bedeutung von Rechtsform und Verfahren im Verwaltungsrecht, Heidelberg 1982.

Schmidt-Aßmann E., Die Lehre von den Rechtsformen des Verwaltungshandelns. Ihre Bedeutung im System des Verwaltungsrechts und für das verwaltungsrechtliche Denken der Gegenwart, "Deutsches Verwaltungsblatt” 1989. 
Schmidt-Aßmann E., Ogólne prawo administracyjne jako idea porządku. Założenia i zadania tworzenia systemu prawnoadministracyjnego, tłum. i red. A. Wasilewski, Warszawa 2011.

Schmidt-Preuß M., Kollidierende Privatinteressen im Verwaltungsrecht. Das subjektive öffentliche Recht im multipolaren Verwaltungsrechtsverhältnis, Berlin 1992.

Schulte M., Schlichtes Verwaltungshandeln. Verfassungs- und verwaltungsrechtsdogmatische Strukturüberlegungen am Beispiel des Umweltrechts, Tübingen 1995.

Starościak J., Stosunek administracyjnoprawny, w: System prawa administracyjnego, t. 3, pod red. T. Rabskiej, J. Łętowskiego, Warszawa 1978.

Stober R., Verwaltungsrecht I. Ein Studienbuch, München 2017.

Turreg K.E., Lehrbuch des Verwaltungsrecht, Berlin 1956.

Wolff H.J., Bachof O., Stober R., Verwaltungsrecht I, München 1994.

Zimmermann J., Prawo administracyjne, Warszawa 2018. 